\title{
THE RELATIONSHIP BETWEEN THE STOCK PRICES AND FINANCIAL RATIOS: EVIDENCE FROM THE PRAGUE STOCK EXCHANGE AND THE POLISH STOCK EXCHANGE
}

\author{
[Vliv finančních ukazatelů na ceny akcií: aplikace na českou a polskou burzu \\ cenných papírů]
}

\author{
Marie Ligocká ${ }^{1}$ \\ ${ }^{1}$ Slezská univerzita, Obchodně podnikatelská fakulta, Univerzitní nám. 1934/3,733 40 Karviná \\ Email:ligocka@opf.slu.cz
}

\begin{abstract}
Stock prices and their fluctuations are analyzed by investors and analytics due to the possibility of achievement the capital earnings. Many variables can affect development of the stock prices; the main categories are macroeconomic factors, industrial variables, and company characteristics. This paper is focused on company characteristics that reflect success of business activities of individual companies. The object of the paper is to investigate the existence of a relationship between selected financial ratios and stock prices of selected manufacturing companies listed on the Prague Stock Exchange and the Polish Stock Exchange. The semi-annual data is analyzed over the $2006-2017$ period. The long-term relationship between the selected financial ratios and stock prices is examined by using the Johansen cointegration test. The existence of short-term cointegration linkages is analyzed using the Vector Error Correction Model (VECM). The findings show that there are sporadic relationships between the stock prices and financial ratios. It seems that investors could be interested in macroeconomic factors, industry variables or they do not have a relevant education to evaluate the financial information.
\end{abstract}

Keywords: cointegration, energy industry, Europe, financial ratios, stock prices.

JEL classification: C32, D24, G32

Doručeno redakci: 3.8.2018; Recenzováno: 6.8.2018; 10.9.2018; Schváleno k publikování: 21.11.2018

\section{Introduction}

Stock prices and their fluctuations are analyzed by investors and analytics due to the explanation of the historical prices and the current prices to identify the variables that could influence the stock prices. Then the investors and analytics can use this information for the prediction of the future stock prices. The motivation of stock prices analysis is to achieve the capital earnings. There are determined three main categories that can affect stock prices are typically determined; macroeconomic factors, industrial variables, and company characteristics. These variables can have different impact on stock prices as some studies show, eg. King (1966) who investigated factors that can influence the stock prices and which ones of them have prevailing impact on stock prices. This paper is focused on the company characteristics that reflect success of business activities of individual companies.

The object of the paper is to investigate the relationship between selected financial ratios and the stock prices of selected manufacturing companies listed on the Prague Stock Exchange and the Polish Stock Exchange. The Prague Stock Exchange is the largest and the oldest organizer of the securities market in the Czech Republic. The market capitalization of the standard market was 38.68 bil. CZK, the market capitalization of the prime market was 1153.86 bil. CZK and the market capitalization of the free market was 19720.09 bil. CZK in October 2018. The Prague Stock Exchange has a marginal position in comparison with world financial centres but despite that, it is recommended to focus on the Czech stock market because the Czech Republic was the first post-communist country that has become a wealthy 
member of the World Bank Group. The Czech crown also represented a safe haven during the global financial crisis due to the relative stability of the country. The Czech stock market can be interesting for investors. In recent years, the Polish Stock Exchange has become one of Europe's most dynamic IPO markets with market capitalisation 1,203.91 bil. PLN in October 2018, of which1 187,56 bil. PLN is market capitalisation of the main market. In addition, Polish Stock Exchange has a derivatives trading platform has grown to become the largest in Central and Eastern Europe.

Three manufacturing Czech companies and three manufacturing Polish companies are included. The manufacturing industry is an important part of the Czech and Polish economy and has a significant position in the competitive environment due to the foreign capital and engaging in the regional and global value chains. The manufacturing industry had a share of $27 \%$ of the GDP in the Czech Republic and a share of $19.3 \%$ of the GDP in Poland in 2015. This part of the industrial production influences the economy of the Czech Republic and Poland because it processes agriculture and mining raw materials in many industries. The financial ratios include the return on assets, the return on equity, the return on sales, the current ratio, the financial leverage, the debt ratio, and the equity ratio. All data is used on semi-annual frequency from 2006 to 2017.

The paper is divided into several sections. The first one is the Introduction, the Review of the Literature follows. The third section is the Data and Methodology, the Results are contained in the fourth section. The final section is the Conclusion.

\section{Review of the Literature}

The empirical literature that analyzes the relationship between financial ratios and stock prices or stock returns is focused on many stock markets. The different approach to the publishing of financial information and its availability can reflect the number of studies that emphasizes the relationship between stock prices and financial ratios on individual stock markets. More of studies are focused on the developed stock markets as the US or Asian stock markets. But the research that is oriented on European markets is not so wide. Therefore the empirical literature discusses the relationship between financial ratios and the stock prices of companies listed on the European stock markets and Asian stock markets are considered.

Asteriou and Dimitropoulos (2009) examined an impact of selected financial ratios on stock returns of 101 non-financial companies listed at the Athens Stock Exchange from 1995 to 2004. The results show that the ratios of working capital to total assets and net profit to sales (ROS) have a negative impact on stock returns, while the ratios of net profit to total assets (ROA) and sales to total assets affect returns positively. Bistrova et al. (2013) tried to determine that there is a robust relationship between the firms' market performance and their economic performance. They analyzed 117 companies listed on Central European stock exchanges (Croatia, Czech Republic, Estonia, Hungary, Latvia, Lithuania, Romania, Poland, Slovakia, Slovenia). The findings show that there does not exist strong relationship between company's economic and market performance in CEE stock markets.

Dadrasmoghadam and Akbari (2015) examined relationship between selected financial ratios and stock prices of agriculture-related companies listed on Iran Stock Exchange from 1999 to 2009. The findings show that the current ratio, the ROA and the ROE have a positive effect on stock prices and the influence of the financial leverage is negative. Dima et al. (2013) analyzed impact of selected financial ratios on stock prices included in FTSE 100, CAC 40, DAX, OMX over the 2003 - 2011 period. The ROA and the current ratio have a positive 
impact on stock prices. Their results support the idea that there are differences in the reactions of European and United States' stock prices to the financial information.

Dzikevičius and Šaranda (2011) examined the relationship between stock prices and selected financial ratios. They used 5 companies listed on the Lithuanian Stock Exchange and covers the period of 2007 - 2010. The authors identified different relationship between the stock prices and financial ratios; particularly the positive impact of the equity ratio (ER), the positive influence of the debt ratio (DR), the impact of the ROA and the ROE was both, positive and negative. Moreover, they think that potential investors do not evaluate the performance of the companies appropriately. Kohansal et al. (2013) explored linkages between financial ratios and stock prices of food companies listed on the Iran Stock Exchange from 1992 to 2010. The results indicate that the stock prices of food companies were influenced positively by the current ratio (L3) and by the financial leverage. The impact of the ROA and the ROE was statistically insignificant.

Martani et al. (2009) analyzed the affect of selected microeconomic factors on stock returns of manufacturing companies listed on the Indonesia Stock Exchange between 2003 - 2006. The study shows that profitability, turnover and market ratio have a significant impact on the stock return. The impact of the current ratio (L3) is negative and the influence of financial leverage is positive but statistically insignificant. Muradoglu and Sivaprasad (2009) investigated the impact of a firm's leverage on the stock returns. They used 788 nonfinantial companies listed on the London Stock Exchange over the 1980 - 2008 period. They used data of 9 main industries: Oil \& Gas, Basic Materials, Industrials, Consumer Goods, Healthcare, Consumer Services, Telecommunications, Utilities, and Technology. The results showed that financial leverage has a negative relation to the stock returns in the sectors of Industrials. Ozlen (2014) tried to identify the effect of selected microeconomic variables on the stock values of 48 companies listed on the Istanbul Stock Exchange. The data includes following sectors: electric, food, communication, paper, chemistry, metal-main, metal-product, stone, textile, commerce, and transportation. The results show the positive effect of current ratio (L3) on stock prices in the electric sector. The prevailing impact of debt ratio is positive in selected sectors.

\section{Data and Methodology}

The three manufacturing companies listed on the Prague Stock Exchange are considered; Čez, Unipetrol and Toma. These companies are selected due to the most similar business profile. The main subject of business activity of the company Čez is electricity sales, production, distribution and sale of heat. The company Unipetrol processes crude oil and make petrochemical products. And the company Toma operates in the yields of tanning, chemical production and provides energy services. And three manufacturing companies listed on the Polish Stock Exchange; namely Skotan, Grupa Lotos and PKN Orlen. The company Lotos is oil company specialized in production of of unleaded gasoline, diesel, fuel oils, aviation fuels, motor and industrial lubricants, bitumens and waxes. The PKN Orlen makes petrochemical products, fuels, electricity and thermal energy. The company Skotan is involved in the oil industry, the company produces biofuels and electrical energy from waste gas and from hydrogen. The paper is focused on determination the variables that can affect the stock prices of Czech analyzed companies, and a comparison with Polish companies that are the most similar in a value of total assets and their business activity. The results of the company Čez are compared with the company PKN Orlen, the findings of the company Unipetrol are compared with the company Lotos, and the results of the company Toma are compared with 
the company Skotan. The Polish stock market is selected because it is the most developed stock market in the Central and Eastern Europe.

The dataset covers the period 2006 - 2017 and all data time series are used on semi-annual frequency. Data on stock prices are from Yahoo Finance and values are calculated as average of semi-annual values. All financial ratios were calculated by using standard methods of financial analysis. Financial ratios are selected with accordance with variables that were analyzed in thus far published studies included in Review of the Literature. The financial ratios considered are the return on assets (ROA), the return on equity (ROE), the return on sales (ROS), the current ratio (L3), the financial leverage (Leverage), the debt ratio (DR) and the equity ratio (ER).

The ROA is a ratio of profitability that measures how well a company is generating profits from its total assets. The ROA reflects the total effectivity of the companies in generating the profit. The ROA is calculated as:

$$
R O A=\frac{\text { EarningsafterTaxes }}{\text { Total Assets }}
$$

The ROE measures a profitability of companies that is generated with the money invested by investors. The ROE is calculated as:

$$
R O E=\frac{\text { EarningsafterTaxes }}{\text { Equity Capital }}
$$

The ROS is a ratio of profitability that reflects efficiency of a company in generating profits from its revenue. The ROS is calculated as:

$$
R O S=\frac{\text { EarningsafterTaxes }}{\text { Total Sales }}
$$

The L3 shows the ability of short-term assets to cover immediate liabilities. This indicator is important due to the payment ability of the company. The long-term payment ability of company is important because of the payment of liabilities. The L3 is calculated as:

$$
L 3=\frac{\text { Currents Assets }}{\text { Short }- \text { term Liabilities }}
$$

The Leverage is related to the profitability ratios. The Leverage gives information how the capital structure changes can influence the ROE. The Leverage is calculated as:

$$
F L=\frac{\text { Total Assets }}{\text { Shareholders'Equity }}
$$

The DR measures the extent of using the debt financing. The level of debt capital can affect profitability of the company. The DR is calculated as: 


$$
D R=\frac{\text { Liabilities }}{\text { Total Assets }}
$$

The ER presents how much own capital a company is using to finance its assets and reflects the share of total assets that is financed by the shareholders' capital. The ER is calculated as:

$$
E R=\frac{\text { Own Capital }}{\text { Total Assets }}
$$

Before the empirical estimations, the descriptive statistics of total assets, earnings after taxes (EAT) and sales is presented in Table 1. The mean, median, maximum and minimum are specified in thousand CZK. The maximum value of total assets is 663.72 bil. CZK and the minimum value of total assets is 357.12 bil. CZK for Čez. The maximum value of sales of Čez was 217 bil. CZK and the maximum EAT was 51.85 bil. CZK in analyzed period. The significantly higher values of Čez can be considered as a consequence of a monopoly position of the company on the market. The maximum value of Toma's total assets is 4.3 bil. CZK and the minimum value of total assets is 1.47 bil. CZK. The maximum value of sales of Toma was 417.75 mil. CZK and the maximum EAT was 135.8 mil. CZK. The company Unipetrol detected the maximum value of total assets at the level 76.61 bil. CZK and the minimum value of total assets at the level 28.96 bil CZK. The maximum value of sales of Unipetrol was 124 bil. CZK and the maximum EAT was 8.65 bil. CZK.

\begin{tabular}{|c|c|c|c|c|}
\hline Company & Variables & Total assets & EAT & Sales \\
\hline \multirow{4}{*}{,$\underbrace{N}$} & Mean & $551,510,400$ & $26,170,790$ & $147,575,300$ \\
\hline & Median & $595,347,500$ & $23,180,500$ & $136,342,500$ \\
\hline & Maximum & $663,723,000$ & $51,855,000$ & $217,273,000$ \\
\hline & Minimum & $357,129,000$ & $13,797,000$ & $77,183,000$ \\
\hline \multirow{4}{*}{ 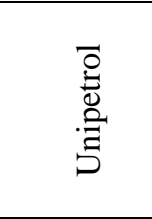 } & Mean & $59,820,123$ & $2,777,381$ & $80,040,967$ \\
\hline & Median & $58,729,903$ & $1,544,874$ & $72,243,379$ \\
\hline & Maximum & $76,612,233$ & $8,659,000$ & $124,000,000$ \\
\hline & Minimum & $28,966,238$ & $65,691.0$ & $38,237,000$ \\
\hline \multirow{4}{*}{$\stackrel{\widetilde{\Xi}}{\varrho}$} & Mean & $2,836,445$ & $48,398.7$ & $279,489.6$ \\
\hline & Median & $3,283,827$ & $36,496.0$ & $290,156.5$ \\
\hline & Maximum & $4,308,269$ & $135,808.0$ & $417,759.0$ \\
\hline & Minimum & $1,471,641$ & $7,621.0$ & $133,463.0$ \\
\hline
\end{tabular}

Table 1: Descriptive Statistics of Czech companies

Source: Authors'calculations.

In Table 2, the descriptive statistics of selected Polish companies is presented. The mean, median, maximum and minimum are specified in thousand CZK. The maximum value of PKN Orlen's total assets is 362.27 bil. CZK and the minimum value of total assets is 211.73 bil. CZK. The maximum value of PKN Orlen's sales was 716.61 bil. CZK and the maximum EAT was 537.46 bil. CZK. The maximum value of total assets is 126.43 bil. CZK and the minimum value of total assets is 34.72 bil. CZK for Grupa Lotos. The maximum value of sales of Grupa Lotos was 197.73 bil. CZK and the maximum EAT was 9.98 bil. CZK in the period 2006 - 2017. The maximum value of Skotan's total assets is 1.63 bil. CZK and the minimum value of total assets is 44.11 mil. CZK. The maximum value of Skotan's sales was 2.79 bil. CZK and the maximum EAT was 366.69 bil. CZK. The total sales of Skotan were 0 
CZK in 2012 due to the fact that company did not make activities related to commercial activities.

Table 2: Descriptive Statistics of Polish companies

\begin{tabular}{|c|c|c|c|c|}
\hline Company & Variables & Total assets & EAT & Sales \\
\hline \multirow{4}{*}{ 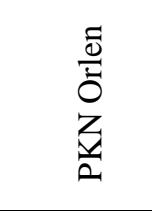 } & Mean & $298,884,445.5$ & $9,478,046.8$ & $378,990,499.2$ \\
\hline & Median & $303,835,605.2$ & $12,168,145.6$ & $337,363,637.3$ \\
\hline & Maximum & $362,273,275.2$ & $537,462,000$ & $716,616,000$ \\
\hline & Minimum & $211,730,897.5$ & $-500,454,755.4$ & $148,549,641.7$ \\
\hline \multirow{4}{*}{ 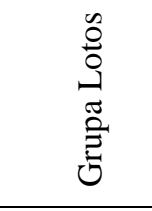 } & Mean & $97,188,166.5$ & $2,528,955.1$ & $95,176,500.0$ \\
\hline & Median & $113,553,502.2$ & $2,377,161.5$ & $82,463,547.1$ \\
\hline & Maximum & $126,430,172.1$ & $9,983,655.2$ & $197,732,269.8$ \\
\hline & Minimum & $34,722,123.3$ & $-2,090,297.2$ & $33,570,378.1$ \\
\hline \multirow{4}{*}{$\begin{array}{l}\tilde{\Xi} \\
\frac{\tilde{0}}{0} \\
\tilde{\sigma}\end{array}$} & Mean & $570,910.8$ & $-19,131.6$ & $345,907.0$ \\
\hline & Median & $498,713.9$ & $-14,132.2$ & $6,046.4$ \\
\hline & Maximum & $1,634,493.6$ & $366,698.3$ & $2,792,174.808$ \\
\hline & Minimum & $44,119.6$ & $-413,786.0$ & 0 \\
\hline
\end{tabular}

Source: Authors'calculations.

The employed methodology follows. First, the stationarity of the time series was tested. The Augmented Dickey-Fuller (ADF) test to verify whether the time series are stationary was used. Then, the data was subjected to correlation analyses to determine a linear relationship between financial ratios and stock prices of selected companies. Further, the analysis of longterm equilibrium relationships by the Johansen test, determining the presence of cointegrating vectors as a VAR; the equation for the considered VAR model is in accordance with Johansen and Juselius (1990):

$$
\Delta Y_{t}=C_{0}+\sum_{i=1}^{p-1} \Gamma_{i} \Delta Y_{t-1}+\Pi Y_{t-1}+\eta_{t}
$$

where $Y t$ is a vector of non-stationary variables, $C_{0}$ is a constant and $\eta_{t}$ is the white noise term. The information in the coefficient matrix between the levels of $\Pi$ is decomposed as $\Pi=\alpha \beta^{\prime}$, where the relevant elements of the $\alpha$ matrix are adjustment coefficients, and the $\beta$ matrix contains the cointegrating vectors. The first likelihood ratio for the null hypothesis of the precise $r$ cointegrating vectors against the alternative $r+1$ vector is known as the maximum eigenvalue statistic. The second statistic for the hypothesis of at most $r$ cointegrating vectors against the alternative is known as the Trace statistic.

If the factors are non-stationary and are cointegrated, the method to investigate the issue of causation, the Vector Error Correction Model (VECM) is used. The VECM specification can be defined as (Johansen and Juselius, 1990):

$$
\Delta y_{t}=\Pi y_{t-k}+\Gamma_{1} \Delta y_{t-1}+\Gamma_{2} \Delta y_{t-2}+\ldots+\Gamma_{k-1} \Delta y_{t-(k-1)}+u_{t}
$$

\section{Results}

At the beginning, the correlation coefficients between the stock prices and selected financial ratios are presented in Table 3. The stock prices of the company Čez show a statistically 
significant correlation coefficients with the ROA, the ROE, the ROS, the L3, and the DR. The stock prices of the firm Toma demonstrate statistically significant correlation coefficients with the ROA, the ROE, the ROS and the ER. Then, the stock prices of the company PKN Orlen demonstrated statistically significant correlation coefficients with the Leverage and the DR. The stock prices of the company Grupa Lotos detected statistically significant correlation coefficients with the ROA, the ROS, the Leverage, the DR and the ER. The stock prices of the company Skotan show statistically significant correlation coefficient with the DR. Other correlation coefficients are statistically insignificant. Relations between the stock prices and financial ratios can be related to the individual financial situation of the selected companies that reflects the value of financial ratios and can has an impact on a causal relationship between the factors.

Table 3: Correlation Coefficients

\begin{tabular}{|l|l|l|l|l|l|l|}
\hline Variables & Čez & Unipetrol & Toma & PKN Orlen & Grupa Lotos & Skotan \\
\hline ROA & $0.6249 *$ & 0.1121 & $0.5853^{*}$ & 0.0260 & $0.4473^{* *}$ & 0.2584 \\
\hline ROE & $0.5374 *$ & 0.1008 & $0.5685^{*}$ & 0.2032 & 0.3418 & 0.1639 \\
\hline ROS & $0.5007 * *$ & 0.1315 & $0.4791 * *$ & 0.0595 & $0.3561 * * *$ & 0.1644 \\
\hline L3 & $-0.5672 *$ & -0.0176 & 0.0973 & 0.2474 & 0.0860 & 0.2333 \\
\hline Leverage & -0.1030 & 0.0534 & 0.0593 & $-0.4608 * *$ & $-0.5451 *$ & -0.1999 \\
\hline DR & $-0.7353^{*}$ & 0.1232 & 0.3242 & $-0.3833^{* * *}$ & $-0.5815^{*}$ & $-0.3898^{* * *}$ \\
\hline ER & 0.1499 & -0.2043 & $-0.5391 *$ & 0.0169 & $0.5132 * *$ & 0.2723 \\
\hline
\end{tabular}

Note: *, ** and *** denote significance at the $1 \%, 5 \%$ and $10 \%$ levels.

Source: Authors'calculations.

The results of the Johansen cointegration test follow. The Trace statistics and the Max-Eigen Statistics are used. Two cointegrating vectors are revealed for two models of the company Čez as Table 4 shows. According to the findings, it is possible to confirm that stock prices of the company Čez were affected by the ROA and the ROE. The influence of the ROA and the ROE was positive that is consistent with the theory and can be related to the relatively stable development of the profitability over the analyzed period. Other of selected financial ratios did not have an impact on stock prices of the company Čez.

Table 4: Results of the Johansen test $-\check{C} e z$

\begin{tabular}{|c|c|c|}
\hline & $\mathrm{r}=0$ & $\mathrm{r} \leq 1$ \\
\hline \multicolumn{3}{|l|}{ Stock prices/ROA } \\
\hline Trace Statistics & $27.8626 *$ & $7.9859 * * *$ \\
\hline Max-Eigen Statistics & $19.8767 *$ & $7.9859 * * *$ \\
\hline \multicolumn{3}{|l|}{ Stock prices/ROE } \\
\hline Trace Statistics & $30.0969 *$ & $8.0744 * * *$ \\
\hline Max-Eigen Statistics & $22.0225 *$ & $8.0744 * * *$ \\
\hline
\end{tabular}

Note: *, ** and *** denote significance at the $1 \%, 5 \%$ and $10 \%$ levels.

Source: Authors'calculations.

The findings for the company PKN Orlen show that there is determined one cointegrating vector for five models. Then, there are two cointegrating vectors for two models but it is confirmed only by the Trace Statistics. These results mean, the stock prices of the company PKN Orlen were not influenced by selected financial ratios. Differences of the results for the $\breve{C}$ ez and PKN Orlen can be related to the monopolistic position of $\breve{\mathrm{C} e z}$ as a producer of elektricity in the Czech Republic. Polish companies do not have a privileged position on the market, there are many companies with different diversification of the commercial activities. 
And there is no clear formulation of the Polish energy policy, therefore investors could be focused on industrial variables, that they can consider as more important.

Table 5: Results of the Johansen test - PKN Orlen

\begin{tabular}{|c|c|c|}
\hline & $\mathrm{r}=0$ & $\mathrm{r} \leq 1$ \\
\hline \multicolumn{3}{|l|}{ Stock prices/ROA } \\
\hline Trace Statistics & $24.6118 * *$ & 6.9146 \\
\hline Max-Eigen Statistics & $17.6971 * *$ & 6.9146 \\
\hline \multicolumn{3}{|l|}{ Stock prices/ROE } \\
\hline Trace Statistics & $29.3497 *$ & 3.6519 \\
\hline Max-Eigen Statistics & $25.6978 *$ & 3.6519 \\
\hline \multicolumn{3}{|l|}{ Stock prices/ROS } \\
\hline Trace Statistics & $20.4280 * *$ & 2.8439 \\
\hline Max-Eigen Statistics & $17.5840 * *$ & 2.8439 \\
\hline \multicolumn{3}{|l|}{ Stock prices/Leverage } \\
\hline Trace Statistics & $18.5857 * * *$ & 4.1090 \\
\hline Max-Eigen Statistics & $14.4766 * * *$ & 4.1090 \\
\hline \multicolumn{3}{|l|}{ Stock prices/L3 } \\
\hline Trace Statistics & $23.9196 * *$ & $10.3451 * *$ \\
\hline Max-Eigen Statistics & 13.5744 & $10.3451 * *$ \\
\hline \multicolumn{3}{|l|}{ Stock prices/DR } \\
\hline Trace Statistics & $18.3500 * * *$ & $7.7213 * * *$ \\
\hline Max-Eigen Statistics & 10.6286 & $7.7213 * * *$ \\
\hline \multicolumn{3}{|l|}{ Stock prices/ER } \\
\hline Trace Statistics & $32.9086 *$ & 3.1848 \\
\hline Max-Eigen Statistics & $29.7238^{*}$ & 3.1848 \\
\hline
\end{tabular}

Note: *, ** and *** denote significance at the $1 \%, 5 \%$ and $10 \%$ levels.

Source: Authors'calculations.

One cointegrating vector is detected for two models of the company Toma. The results in Table 6 show that the stock prices of the company Toma were not influenced by selected financial ratios. Investors could consider as important different type of information or they are not able to evaluate information in financial statements appropriately, and it is why, they do not monitor development of financial ratios.

Table 6: Results of the Johansen test - Toma

\begin{tabular}{|c|c|c|}
\hline & $\mathrm{r}=0$ & $\mathrm{r} \leq 1$ \\
\hline \multicolumn{3}{|l|}{ Stock prices/L3 } \\
\hline Trace Statistics & $18.3548 * *$ & 3.7666 \\
\hline Max-Eigen Statistics & $14.5882 * *$ & 3.7666 \\
\hline \multicolumn{3}{|l|}{ Stock prices/ER } \\
\hline Trace Statistics & $22.1387 * *$ & 5.3467 \\
\hline Max-Eigen Statistics & $16.7919 * *$ & 5.3467 \\
\hline
\end{tabular}

Note: *, ** and *** denote significance at the $1 \%, 5 \%$ and $10 \%$ levels.

Source: Authors'calculations.

The statistically significant results of Johansen cointegration test are demonstrated for the company Skotan in Table 7. One cointegrating vector is revealed for four models and two 
cointegrating vectors are detected for three models of the company Skotan. According to the results the stock prices of the company Skotan were affected by the ROA, and the ER positively and by the Leverage negatively. The positive impact of the ROA can be related to the higher value of the ROA in periods when company generated the profit, despite the negative value of the ROA in some years. Investors could consider a higher share of the own capital asi positive due to the lower risk of the own capital because of the negative value of the profit in some years. But the negative impact of the Leverage show that there is not appropriate capital strucutre with positive influence on the ROA. But it seems that investors do not have a relevant education or they are not able to evaluate financial information right.

Table 7: Results of the Johansen test - Skotan

\begin{tabular}{|c|c|c|}
\hline & $\mathrm{r}=0$ & $\mathrm{r} \leq 1$ \\
\hline \multicolumn{3}{|l|}{ Stock prices/ROA } \\
\hline Trace Statistics & $84.6803 *$ & $8.5445 * * *$ \\
\hline Max-Eigen Statistics & $76.1357 *$ & $8.5445 * * *$ \\
\hline \multicolumn{3}{|l|}{ Stock prices/ROE } \\
\hline Trace Statistics & $83.0300 *$ & 7.3150 \\
\hline Max-Eigen Statistics & $75.7150 *$ & 7.3150 \\
\hline \multicolumn{3}{|l|}{ Stock prices/ROS } \\
\hline Trace Statistics & $24.1679 * *$ & 3.2983 \\
\hline Max-Eigen Statistics & $20.8695 * *$ & 3.2983 \\
\hline \multicolumn{3}{|l|}{ Stock prices/Leverage } \\
\hline Trace Statistics & $85.5356^{*}$ & $8.4356^{* * * *}$ \\
\hline Max-Eigen Statistics & $77.0999 *$ & $8.4356 * * *$ \\
\hline \multicolumn{3}{|l|}{ Stock prices/L3 } \\
\hline Trace Statistics & $96.0094 *$ & 2.4706 \\
\hline Max-Eigen Statistics & $93.5387 *$ & 2.4706 \\
\hline \multicolumn{3}{|l|}{ Stock prices/DR } \\
\hline Trace Statistics & $21.5578 * *$ & 3.3998 \\
\hline Max-Eigen Statistics & $18.1579 * *$ & 3.3998 \\
\hline \multicolumn{3}{|l|}{ Stock prices/ER } \\
\hline Trace Statistics & $90.9939 *$ & $8.3324 * * *$ \\
\hline Max-Eigen Statistics & $82.6615 *$ & $8.3324 * * *$ \\
\hline
\end{tabular}

Note: $*, * *$ and $* * *$ denote significance at the $1 \%, 5 \%$ and $10 \%$ levels.

Source: Authors'calculations.

Further, one cointegrating vector is revealed for four models of the company Unipetrol as Table 8 shows. According to the findings, the stock prices of the company Unipetrol were not affected by selected financial ratios. The similar findings are demonstrated for the company Grupa Lotos. The stock prices of the company Grupa Lotos were not influenced by any of selected financial ratios. Despite the fact, the Polish stock market is more developed, it seems that investors are not interested about company characteristics or they do not evaluate this information as important in a relation with the stock prices. 
Table 8: Results of the Johansen test - Unipetrol and Grupa Lotos

\begin{tabular}{|c|c|c|}
\hline \multicolumn{3}{|c|}{ Unipetrol } \\
\hline & $\mathrm{r}=0$ & $\mathrm{r} \leq 1$ \\
\hline \multicolumn{3}{|l|}{ Stock prices/ROA } \\
\hline Trace Statistics & $20.3402 * *$ & 5.5462 \\
\hline Max-Eigen Statistics & $14.7940 * * *$ & 5.5462 \\
\hline \multicolumn{3}{|l|}{ Stock prices/ROE } \\
\hline Trace Statistics & $27.3285^{*}$ & 4.5364 \\
\hline Max-Eigen Statistics & $22.7920 *$ & 4.5364 \\
\hline \multicolumn{3}{|l|}{ Stock prices/ROS } \\
\hline Trace Statistics & $21.9286 * *$ & 6.0627 \\
\hline Max-Eigen Statistics & $15.8659 * *$ & 6.0627 \\
\hline \multicolumn{3}{|l|}{ Stock prices/Leverage } \\
\hline Trace Statistics & $30.8427 *$ & 6.7887 \\
\hline Max-Eigen Statistics & $24.0540 *$ & 6.7887 \\
\hline \multicolumn{3}{|c|}{ Grupa Lotos } \\
\hline & $\mathrm{r}=0$ & $\mathrm{r} \leq 1$ \\
\hline \multicolumn{3}{|l|}{ Stock prices/Leverage } \\
\hline Trace Statistics & $20.7905 * *$ & 3.0431 \\
\hline Max-Eigen Statistics & $17.7473 * *$ & 3.0431 \\
\hline \multicolumn{3}{|l|}{ Stock prices/ER } \\
\hline Trace Statistics & $20.4683 * *$ & 3.3200 \\
\hline Max-Eigen Statistics & $17.1483 * *$ & 3.3200 \\
\hline
\end{tabular}

Note: *, ** and *** denote significance at the $1 \%, 5 \%$ and $10 \%$ levels.

Source: Authors'calculations.

The statistically significant findings of the Johansen cointegration test are complemented by the VECM estimations. The significance of each model is computed using the F-statistics coefficient and the coefficient R-squared (R2). Table 9 shows only the statistically significant results that are confirmed for three models of the company Skotan. The existence of the shortterm deviations are confirmed between stock prices of the company Skotan, the ROA, the Leverage and the ER. The coefficients of the cointegration equation (CointEq1) are negative in all cases. This indicates that an increase in financial ratios has a negative influence on stock prices. The ROA has a negative value in some years that investors can evaluated as threat in generating the profit of the company, and they have a negative expectations about profitability development. The negative impact of the ER is related to the high share of own capital that can have a negative influence on the profitability of the company. This idea is also supported by result for the Leverage because the company did not use higher share of the debt capital that can be related to the positive leverage effect. According to the results, the correction to the long-run equilibrium should occur with probability $59 \%$ (ROA), $58 \%$ (Leverage) and 59 $\%$ (ER). 
Table 9: Results of the VECM - Skotan

\begin{tabular}{|c|c|c|c|c|c|}
\hline CointEq1 & $\begin{array}{l}-0.5956 \\
(0.0279) \\
{[-21.3116]}\end{array}$ & CointEq1 & $\begin{array}{l}-0.5881 \\
(0.0270) \\
{[-21.7463]}\end{array}$ & CointEq1 & $\begin{array}{l}-0.5981 \\
(0.0233) \\
{[-25.5832]}\end{array}$ \\
\hline PRICE(-1) & $\begin{array}{c}-0.0188 \\
(0.0429) \\
{[-0.4399]}\end{array}$ & PRICE(-1) & $\begin{array}{c}-0.0123 \\
(0.0417) \\
{[-0.2960]}\end{array}$ & PRICE(-1) & $\begin{array}{c}-0.0290 \\
(0.0355) \\
{[-0.8173]}\end{array}$ \\
\hline $\operatorname{ROA}(-1)$ & $\begin{array}{c}-0.8380 \\
(0.2893) \\
{[-2.8959]}\end{array}$ & Leverage(-1) & $\begin{array}{c}0.1163 \\
(0.0865) \\
{[1.3443]} \\
\end{array}$ & $\mathrm{ER}(-1)$ & $\begin{array}{c}-1.6103 \\
(1.2258) \\
{[-1.3136]}\end{array}$ \\
\hline Constant & $\begin{array}{c}-1.5533 \\
(0.2002) \\
{[-7.7572]}\end{array}$ & Constant & $\begin{array}{c}-1.5533 \\
(0.1972) \\
{[-7.8764]}\end{array}$ & Constant & $\begin{array}{c}-1.5970 \\
(0.1683) \\
{[-9.4877]}\end{array}$ \\
\hline $\mathrm{R} 2$ & 0.9618 & $\mathrm{R} 2$ & 0.9633 & $\mathrm{R} 2$ & 0.9739 \\
\hline Adj. R2 & 0.9555 & Adj. R2 & 0.9572 & Adj. R2 & 0.9696 \\
\hline F-statistics & 151.4479 & F-statistics & 157.6599 & F-statistics & 224.6257 \\
\hline
\end{tabular}

Note: Standard errors are in ( ) and t-statistics are in [ ].

Source: Authors'calculations.

\section{Conclusion}

The object of the paper was to investigate the existence of a relationship between selected financial ratios and the stock prices of selected manufacturing companies listed on the Prague Stock Exchange and the Polish Stock Exchange.

The long-term relationship between selected financial ratios and the stock prices of manufacturing companies was analyzed by using the Johansen cointegration test. The findings show that the stock prices of the company Čez were affected positively by the ROA and the ROE. These results are consistent with Asteriou and Dimitropoulos (2009) who detected a positive impact of the ROA on stock returns; then with Dzikevičius and Šaranda (2011) and Dadrasmoghadam and Akbari (2015) who determined a positive effect of the ROA and the ROE on stock prices. The stock prices of the company Toma and Unipetrol were not influenced by any of selected financial ratios. The results for the company Toma and Unipetrol can be influenced by trading on the standard market and findings for the company Čez can be affected by trading on the prime market and related interest in stocks of companies, that can reflect higher investors' information about financial situation of company Čez. The significant impact of the profitability ratios on the stock prices of the company Čez can be a reflection of monopolistic position of the company Čez as a producer of electricity in the Czech Republic. Investors can consider the monopolistic position of the company Čez as a garantee of financial stability of company and they can focus only on the profitability ratios.

Furthermore, the results confirmed that the stock prices of the company Skotan were influenced by the ROA, the Leverage and the ER. The negative impact of the Leverage is consistent with Dadrasmoghadam and Akbari (2015) and positive influcence of the ROA and the ER is in accordance with Dima et al. (2013) and Ozlen (2014). The company Skotan changed its business profil in 2006, and there was generated a negative profit in some years, that can be a cause why investors are interested about financial situation of the company Skotan more than in other companies. The stock prices of the company Grupa Lotos and PKN Skotan were not affected by any of selected financial ratios. The results can be related to the fact that on the Polish Stock Exchange there is trading with high number of companies with 
different market shares and there is no clear formulation of the Polish energy policy. And this support an idea that investors can be focused mainly on macroecomic factors or industrial variables that reflect complex problematics of industry and business climate.

The findings of the Johansen cointegration test were supplemented by using VECM estimations to investigate short-term dynamics. The results show the existence of the shortterm deviations between the stock prices of the company Skotan and the ROA, the Leverage and the ER. The negative impact of the ER on the stock prices of the company Skotan is in accordance with the theory. The positive influence of the ROA is consistent with Asteriou and Dimitropoulos (2009) who determined a positive impact of the ROA on the stock returns and negative impact of the Leverage is in accordance with Muradoglu and Sivaprasad (2009) whose study showed the negative impact of the Leverage on the stock returns.

The findings show that there does not exist strong relationship between financial information and stock prices in selected Central European stock markets, as study of Bistrova et al. (2013) proved. It seems that results can be also affected by a wrong evaluation of the financial information because the relevant education level of the investors is not yet too high on the Central European stock markets as Bistrova et al. (2013) assume.

\section{Acknowledgement}

Publication of this paper was supported by the Student Grant System of Silesian University in Opava within the project "The effect of fundamental factors and corporate governance on stock prices (no. 23/2016)." The support is greatly acknowledged.

\section{References}

[1] BISTROVA, J., N. LACE and J. TITKO, 2013. CEE companies: Economic vs. market performance. In: 17th World Multi-Conference on Systemics, Cybernetics and Informatics (WMSCI 2013): Proceedings, United States of America, Orlando: International Institue of Informatics and Systemics, s. 1 - 6. ISBN 9781936338887.

[2] DADRASMOGHADAM, A. and S. M. R. AKBARI, 2015. Relationship between Financial Ratios in the Stock Prices of Agriculture - Related Companies Accepted On the Stock Exchange for Iran. Research Journal Of Fisheries And Hydrobiology, 10(9), 586 591. ISSN 1816-9112.

[3] DIMA, B., S. M. DIMA, O. ŞĂRĂMĂT and C. ANGYAL, 2013. Financial Ratios and Stock Prices on Developed Capital Markets. Economic Series, 23(1), 1 - 12.

[4] DIMITROPOULOS, P. and D. ASTERIOU, 2009. The Value Relevance of Financial Statements and Their Impact on Stock Prices, Evidence from Greece. Managerial Auditing Journal, 24(3), 248 - 265. ISSN 0268-6902.

[5] DZIKEVIČIUS, A. and S. ŠARANDA, 2011. Can financial ratios help to forecast stock prices? Journal of Security and Sustainability Issues, 1(2), 147 - 157. ISSN 20297017.

[6] JOHANSEN, S. and K. JUSELIUS, 1990. Maximum likelihood estimation and inference on cointegration-with applications to the demand for money. Oxford Bulletin of Economics and statistics, 52(2), 169-210. ISSN 0305-9049.

[7] KING, B. F., 1966. Market and Industry Factors in Stock Price Behavior. The Journal of Business, 39(1), 139-190. ISSN 0021-9398. 
[8] KOHANSAL, M. R., A. DADRASMOGHAM, K. M. KARMOZDI and A. MOHSENI, 2013. Relationship between financial ratios and stock prices for the food industry firms in Stock Exchange of Iran. World Applied Programming, 3(10). ISSN 2222-2510.

[9] MARTANI, D., MULYONO and R. KHAIRURIZKA, 2009. The effect of financial ratios, firm size, and cash flow from operating activities in the interim report to the stock return. Chinese Business Review, 8(6), 44 - 55. ISSN 1537-1506.

[10] OZLEN, S., 2014. The Effect of Company Fundamentals on Stock Values. European Researcher, 71(3 - 2), 595 - 602. ISSN 2219-8229.

[11] SIVAPRASAD, S. and Y. G. MURADOGLU, 2009. Leverage, stock returns, taxes and industry concentration. SSRN Electronic Journal. [online]. 24 October 2010 [vid. 12 October 2017]. Available at: http://dx.doi.org/10.2139/ssrn.1031987 